8-2007

\title{
Who Survives on Death Row? An Individual and Contextual Analysis
}

David Jacobs

Ohio State University, JACOBS.184@OSU.EDU

Jason T. Carmichael

McGill University

Zhenchao Qian

Ohio State University - Main Campus

Stephanie L. Kent

Cleveland State University, s.l.kent59@csuohio.edu

Follow this and additional works at: https://engagedscholarship.csuohio.edu/clsoc_crim_facpub

Part of the Criminology Commons

How does access to this work benefit you? Let us know!

Publisher's Statement

This research was supported by NSF grant \#0417736.

\section{Repository Citation}

Jacobs, David; Carmichael, Jason T.; Qian, Zhenchao; and Kent, Stephanie L., "Who Survives on Death Row? An Individual and Contextual Analysis" (2007). Sociology \& Criminology Faculty Publications. 107. https://engagedscholarship.csuohio.edu/clsoc_crim_facpub/107

This Article is brought to you for free and open access by the Sociology \& Criminology Department at EngagedScholarship@CSU. It has been accepted for inclusion in Sociology \& Criminology Faculty Publications by an authorized administrator of EngagedScholarship@CSU. For more information, please contact library.es@csuohio.edu. 


\section{Who Survives on Death Row? An Individual and Contextual Analysis}

David Jacobs
The Ohio State University

Jason T. Carmichael

McGill University

\author{
Zhenchao Qian \\ The Ohio State University \\ Stephanie L. Kent \\ Cleveland State University
}

What are the relationships between death row offender attributes, social arrangements, and executions? Partly because public officials control executions, theorists view this sanction as intrinsically political. Although the literature has focused on offender attributes that lead to death sentences, the post-sentencing stage is at least as important. States differ sharply in their willingness to execute and less than 10 percent of those given a death sentence are executed. To correct the resulting problems with censored data, this study uses a discrete-time event history analysis to detect the individual and state-level contextual factors that shape execution probabilities. The findings show that minority death row inmates convicted of killing whites face higher execution probabilities than other capital offenders. Theoretically relevant contextual factors with explanatory power include minority presence in nonlinear form, political ideology, and votes for Republican presidential candidates. Inasmuch as there is little or no systematic research on the individual and contextual factors that influence execution probabilities, these findings fill important gaps in the literature.

$\mathrm{W}^{1}$ hat individual and contextual factors explain what happens to offenders who have been sentenced to death? An execution clearly is the most severe legal punishment, but no systematic research on the combined political and individual factors that determine

Direct correspondence to David Jacobs, Department of Sociology, 300 Bricker Hall, 190 North Oval Mall, The Ohio State University, Columbus, OH 43210 (jacobs.184@osu.edu). We thank Douglas Berman for his valuable advice on criminal procedure law applied to the death penalty and Ruth Peterson for her comments. We are indebted to Dan Tope for his research assistance. We also thank Ohio State colleagues for their comments in presentations at the law school, the political science department, the Criminal Justice Research Center, colleagues at the University of Cincinnati School of Criminal Justice, the editors, and the referees. All data used in this study and in the analyses discussed in the text but not shown are available on request. This research was supported by NSF grant $\# 0417736$. which death row inmates will be executed apparently exists. A few studies describe what happens to these offenders after sentencing (Aarons 1998; Liebman, Fagan, and West 2000), yet there are almost no systematic investigations on the most important determinants of executions. Studies by Spurr (2002) and Blume and Eisenberg (1999) are partial exceptions, but these studies focus only on offender characteristics and ignore environmental conditions. Although studies repeatedly show that victim race is the most important determinant of death sentences, we do not know if this factor influences the fate of offenders on death row because no investigations have determined whether this account explains executions.

The factors that influence execution probabilities are of interest partly because there are such substantial disparities in this outcome. Largely as a result of the appeals process that occurs after a death sentence, less than 10 percent of all offenders on death row ulti- 
mately are executed (Liebman et al. 2000). ${ }^{1}$ There is great variation in the duration of this process as well, apparently because death penalty states differ sharply in their willingness to execute. In many reluctant jurisdictions capital offenders can spend well over two decades on death row, but other states execute in far less time. To assess the determinants of these legal decisions about who will live and who will die, we test theoretically based explanations using an event history approach to discover the factors that influence post-death sentence execution likelihoods.

Trial court studies on the offender attributes that lead to death sentences show that offenders who kill whites are far more likely to receive this sentence (Baldus and Woodworth 2003; Dodge et al. 1990; Paternoster 1991). Yet whether victim race continues to explain the fate of condemned prisoners after they have been sentenced remains a complete mystery. There are good reasons to think that this factor will continue to matter. Yet it is equally plausible that the appellate court decisions that largely determine death row outcomes are unaffected by this consideration that, of course, should not be relevant. In any event, both theoretical considerations and concerns about equity make this relationship between victim race and execution probabilities a critical issue.

This article will provide important evidence about whether the death penalty is administered impartially. But our primary goal is to refine theories of punishment by using a comprehensive approach to gauge the explanatory power of both individual and contextual effects. It is unlikely that judges and the political officials who decide which death row inmates will

\footnotetext{
${ }^{1}$ Local trial courts sentence, but appeals are handled by higher state and federal courts. The first two capital appeals typically are decided by state appellate courts. Condemned offenders then can petition the federal courts. About 41 percent of all death sentences are reversed on first state appeal and about 9.5 percent are reversed in the second. About 40 percent of those who then seek federal relief are successful (Liebman et al. 2000). Most of the remainder are executed. But a few receive executive clemency, some die before execution, and a few are removed from death row for miscellaneous reasons. Almost all of the condemned who obtain appellate relief are resentenced to long prison terms.
}

be executed are unaffected by their political environment, especially because this punishment is such an intensely moral issue. In part because some death row offenders face far lower execution probabilities than those in less lenient jurisdictions (Liebman et al. 2000), we gauge the effects of the sociopolitical environment as well as offender and victim attributes.

There are strong reasons for such a combined approach. Two isolated traditions have coexisted in the literature. Many studies use individual data to explain trial court sentencing, but others rely on aggregate data to study additional criminal justice outcomes. State or national attributes have been used to explain shifts in incarceration rates (Jacobs and Carmichael 2001; Jacobs and Helms 1996; Stucky, Heimer, and Lang 2005; Sutton 2000; Western 2006). The urban conditions that explain police department size (Jacobs 1979; Kent and Jacobs 2005), arrest rates (Brown and Warner 1992), or the use of deadly force by the police (Jacobs and O'Brien 1998) have been researched as well. Yet except for a few studies that assess how community and individual determinants combine to affect the sentencing of non-capital offenders (Helms and Jacobs 2002; Myers and Talarico 1987), there is little research on the combined effects of individual and contextual determinants. But the many results based on aggregate data showing that context is a strong determinant of multiple criminal justice outcomes make it difficult to believe that such environmental factors do not influence post-sentencing decisions about executions.

We therefore use an integrated theoretical approach that emphasizes political explanations and the racial accounts in earlier conflict studies (Turk 1969). An execution is an intrinsically political act. Foucault (1977) views executions as rituals designed to enhance political power by reminding potential miscreants of the state's vast coercive resources. But there are more concrete reasons for studying political effects. Most researchers who first tested conflict explanations hypothesized that larger and therefore more threatening minority populations would increase support for repressive law and order measures. Citizens threatened by expansions in a minority presence often react by demanding harsh criminal justice policies. Because criminal justice agencies are operated by the state, this pressure has to be directed at political officials. By 
assessing the political factors that result from added demands for this severe punishment, we seek to broaden the conflict approach to punishment.

This article therefore offers the promise of filling many important gaps in the sparse literature on post-death sentence execution probabilities by using a survival analysis that adjusts for censoring and assesses both offender and political characteristics. The multiple advantages that result from the inclusion of both individual and contextual factors suggest that this analysis will provide an accurate picture of the post-sentencing death penalty process. Results based on models that assess many explanations are most accurate (Johnston 1984, see note 11), but such an inclusive approach means that the theoretical section cannot focus on only a few explanations.

\section{THEORY}

Inasmuch as scholars claim that race continues to have powerful effects on U.S. politics (Goldfield 1997; Jacobs and Tope 2007; Key 1949), and because the administration of the death penalty is such an intense political issue, racial politics provide the primary conceptual basis for this analysis. Most research on the death sentence focuses on the race of individual offenders and their victims. We assess such micro minority accounts by gauging the explanatory power of various offender-victim minority-majority combinations, but we fill contextual gaps in the literature by analyzing the influence of minority threat in the political environments in which these decisions are made. Ideology also should matter as this penalty is such an intensely moral issue and since we study it in the most direct of all large democracies. In contrast to other nations, U.S. politicians routinely encourage citizens to vote on the basis of their views about capital punishment. Another closely related account suggests that the parochial interests of politicians influence executions. Tactical rhetoric that stresses the depravity of a minority underclass and the need for harsh measures should affect support for this penalty (Beckett 1997) and its probability.

We present the theoretical foundation for four interrelated proposition sets. First, we discuss the conceptual basis for micro-level racial hypotheses derived from the literature on sen- tencing. Second, we present theoretically based hypotheses about the contextual effects of minority threat, political ideology, and partisan politics. At the end of this section, we present justifications for additional explanations for execution probabilities.

\section{INDIVIDUAL EXPLANATIONS: EXTRA-LEGAL Micro Racial Accounts and Legal FACTORS}

If penal measures are best explained by their interrelationships with other social arrangements rather than by their alleged legal purposes (Garland 1990:91), it would be surprising if the most important U.S. social division did not influence the administration of the most severe legal punishment. A conceptual grounding in racial politics therefore should provide the best theoretical foundation for a study that analyzes the administration of the death penalty. In theoretical essays Wacquant $(2000,2001)$ uses arguments about social impurity and taboo to show how the Jim Crow racial caste system persists in socially altered but less conspicuous forms in the contemporary U.S. criminal justice system. To discover if such racial considerations still affect decisions about legal punishments, the question that motivates almost all of the many sentencing studies is whether the trial courts treat minorities the same as nonminorities (Chiricos and Crawford 1995; Walker, Spohn, and DeLone 1996; Zatz 1987).

Findings about non-capital sentences, and those from the less ample literature on the factors that account for death sentences, should provide the best available empirical basis for selecting the individual factors that explain which condemned prisoners will be executed. Despite their number, only a bare majority of the non-capital sentencing studies show that the trial courts give harsher sentences to minorities, but almost as many careful investigations do not find such biases (Chiricos and Crawford 1995; Walker et al. 1996). Studies on the links between offender race and death sentences are even less likely to suggest that white offenders are treated with greater leniency than minorities (Baldus and Woodworth 2003; Dodge et al. 1990; Paternoster 1991). In light of the systematic discrimination faced by African Americans, however, we follow precedent and hypothesize that: The likelihood of executions should be 
greater for African Americans on death row. In some jurisdictions Hispanics are the most threatening minority that faces severe discrimination. It is equally plausible that: Hispanics on death row should face higher execution probabilities than whites.

Offenders convicted of killing whites are particularly likely to be sentenced to death (Baldus and Woodworth 2003; Dodge et al. 1990; Paternoster 1991), especially if the offender is black (Baldus and Woodworth 2003). Wacquant (2000) provides one theoretical foundation for this persistent association when he claims that harsh legal punishments continue to be used to maintain the "symbolic distance needed to prevent the odium of 'amalgamation' with [minorities] considered inferior, rootless, and vile" ( $p$. 380). The ultimate symbolic assault on such a caste system occurs when an underclass minority kills a white. In this research we discover if this account that explains death sentences so well also explains execution probabilities.

Two causal paths seem most plausible. In contrast to the great majority of homicides, media outlets focus on interracial murders, particularly if the victim is white (Bandes 2004, Lipschultz and Hilt 2002). This increased coverage is critical as victories in well-publicized capital trials often help politically ambitious prosecutors reach higher office. But such triumphs must be protected. Prosecutors therefore have strong reasons to vigorously oppose capital appeals that may jeopardize legal victories that are likely to further their political careers. $^{2}$ Even if other facilitative conditions are absent, the media's focus on those murders in which a white was killed by a minority puts added pressure on state appellate court justices to rule against these death row offenders when they appeal (Liebman, Fagan, and West 2002).

\footnotetext{
${ }^{2}$ After a death sentence, local prosecutors can have important effects on the subsequent appeals. For example, their delays in filing for an execution date slow appeals. In fact, any failure to act promptly favors condemned offenders as delayed appeals are not as likely to be vigorously contested. For this and other reasons, the local prosecutor who won an initial death sentence verdict often plays an important role in resisting subsequent appeals, although this role may be informal. Hence, prosecutor commitment to efforts to resist death row appeals should influence execution probabilities.
}

And disregarding these pressures can be costly. State judges who ignored intense public support for particular executions and granted appellate relief to such petitioners have lost their seats in retention elections, even though only the incumbent appears on retention election ballots (Brace and Hall 1997; Bright and Keenan 1995). Hence: African American or Hispanic offenders convicted of murdering a white should be less likely than other offenders to avoid the death chamber.

Most studies of the determinants of non-capital sentencing that assess the effects of gender find that in comparison to females, trial courts give less lenient sentences to males (Bickle and Peterson 1991). This finding may be partially based on a failure to control for the ways offenders participated in their crimes. Women convicted of robbery, for instance, often do not engage in the violence associated with this felony. Inasmuch as their involvement is less pernicious, such offenders receive lighter sentences than their male associates. It nevertheless is reasonable to expect that chivalrous inclinations should reduce female execution probabilities, so: Women on death row should be less likely to be executed than males. Finally, findings show that offenders with prior convictions are sentenced more severely by trial courts. This practice is reasonable as repeat offenders are likely to pose a greater threat to the community after their release or to guards and other inmates while they are imprisoned. Hence: Execution probabilities will be greater for those condemned prisoners with previous convictions.

\section{CONTEXTUAL EXPLANATIONS: RACIAL Threat, Political IDEology, and PARTISANSHIP}

The multiple decisions that ultimately produce an execution do not occur in a social vacuum. A few studies of sentencing decisions for noncapital crimes productively treat the trial courts as complex organizations. Yet analyses of contextual forces external to organizations have sharply increased our understanding of organizational behavior (Perrow 1986; Scott 1987). The multiple findings based on aggregate data that provide such robust explanations for criminal justice outcomes and the strong organization-environment relationships so often uncovered in the organizational literature point 
in the same direction. Both research streams suggest that legal decision makers who are embedded in political environments do not ignore such conditions when they decide if an execution will occur.

RACIAL MIX. The fierce U.S. disputes about race in the past probably make this fissure the most resilient and influential division in contemporary U.S. politics (Goldfield 1997; Jacobs and Tope 2007; Key 1949). A majority's ethnocentric views and that group's inclination to view minorities as trespassers enhance such a group's presumption that they should retain exclusive claims over important rights and privileges (Blalock 1967; Blumer 1958; Bobo and Hutchings 1996). Hostility and entrenched beliefs about a majority's "rightful" position are solidified by the political struggles that occur when minority groups seek to alter these arrangements (Blumer 1958). According to threat theorists, when large minority populations endanger their dominance, whites often react by supporting law and order measures that at least indirectly target these minorities.

Findings are supportive. Racist views are more widespread in cities with more black residents (Fosset and Kiecolt 1989; Quillian 1996; Taylor 1998). An enhanced minority presence produces added votes for anti-minority candidates (Giles and Buckner 1993; Giles and Hertz 1994; Heer 1959) who are likely to endorse harsh criminal punishments. With crime rates held constant, Liska, Lawrence, and Sanchirico (1982) and Quillian and Pager (2001) find that fear of crime is greater in cities or neighborhoods with more black residents. Larger minority populations lead to additional police officers (Jacobs 1979; Kent and Jacobs 2005). Other findings show that the death penalty is likely to be legal in states with the highest percentages of African American residents (Jacobs and Carmichael 2002), while the number of death sentences is greater in states with the largest African American populations (Jacobs, Carmichael, and Kent 2005).

These results suggest that severe punishments will increase in areas after a growth in minority presence. Yet if minority proportions expand and their political influence becomes sufficient, the positive relationship between this threat and punitiveness may reverse. All governors, almost all local prosecutors, and most state appellate justices are elected. Expansions in African American or Hispanic proportions past a threshold should give these minorities enough votes to influence decisions about executions. Hence: The relationship between the percentage of blacks and execution probabilities should be positive if minority presence is modest, but after this percentage reaches a threshold, this association should become negative and executions should diminish. For this sign reversal to occur, a minority need not outnumber other groups. Minority size need only reach the point where their votes may help decide elections, and this proportion can be modest if other voting blocs are evenly matched. This logic and nonlinear findings about death sentence frequency (Jacobs et al. 2005) suggest that an inverted U-shaped relationship between African American presence and executions will be present.

The relationship between Hispanic presence and executions may take a different nonlinear form. In many non-southwestern states, the proportion of Hispanic residents is minute. The median percentage of Hispanics was 2.4 percent in the sampled states, yet the same statistic for blacks was 6.8 percent or 2.9 times greater. As the Hispanic population was so modest in so many states, it is plausible that this population must reach a threshold size before whites see Hispanics as sufficiently threatening. Hence: The nonlinear relationship between the percentage of Hispanic residents and execution probabilities should become increasingly positive only after the comparative size of this ethnic minority reaches a level sufficient to threaten majority Anglos.

Political ideology. Claims that ideology helps shape legal penalties are especially compelling when U.S. sanctions are at issue, as this nation is such an exceptionally direct democracy (Savelsberg 1994; Whitman 2003). The resulting close voter control over criminal punishments, which are decided by bureaucratic experts in the less direct European democracies, ought to make mass ideologies crucial when such intensely moral decisions about who will die must be made. Images of evil and the resulting beliefs about the most appropriate punishments that stem from these assumptions about human nature are a foundational component of political ideologies. Conservatives often see crime as resulting from freely made but amoral 
choices (Lacey 1988). If such presumptions are correct, increases in expected costs should be effective. Many conservatives therefore stress the irreversibility and the deterrent effects of executions. Such views about the efficacy of incapacitation and deterrence provide the basis for empirically dubious conservative claims that a few executions will protect many innocent victims from criminal brutality. ${ }^{3}$

Liberals instead see criminal acts as imposed by circumstances (Garland 2001; Thorne 1990). These acts result from noxious environmental conditions such as poverty or discrimination. Liberals view policies that alleviate these injurious conditions (Taylor, Walton, and Young 1973) and therapeutic efforts to resocialize offenders (Garland 2001) as the best remedies. In contrast to conservatives, liberal survey respondents are far less likely to support the death penalty (Lakoff 1996; Langworthy and Whitehead 1986). Findings corroborate these claims as they show that the most liberal states are unlikely to legalize this punishment (Jacobs and Carmichael 2002). It follows that: Executions should not be as probable where liberal views predominate, as prosecutors and appellate justices should be less likely to endorse this penalty in these jurisdictions.

Political PaRtisanship. Because they seek outcomes that help the prosperous, political parties closer to the right face election obstacles. These parties, for example, usually choose tax policies that benefit their affluent core supporters at the expense of the less affluent (Allen and Campbell 1994). Yet prosperous voters are in the minority. Because such parties have a smaller voter base than their rivals, conservatives often use law and order claims to appeal to less

\footnotetext{
${ }^{3}$ Careful reviews of the multiple empirical studies on this issue conducted by legal scholars (Zimring and Hawkins 1986), criminologists (Hood 1998; Paternoster 1991), sociologists (Bailey and Peterson 1999), and economists (Donohue and Wolfers 2005; Levitt 2002) conclude that the death penalty has no discernable general deterrent effects beyond those imposed by long prison terms. This list of skeptics about the deterrent effects of executions includes a scholar (Levitt 2002) who has published multiple findings showing that imprisonment and other policies designed to control crime are effective deterrents.
}

affluent voters who are more likely to be crime victims and who often live where such risks are greater. Officials in the Nixon and first Bush campaigns for the presidency admit that they emphasized this issue to attract anti-minority voters. ${ }^{4}$ By focusing on street crime and other social problems readily blamed on underclass minorities, Republicans won elections by using this "wedge" issue to gain sufficient votes from less prosperous citizens. Multiple findings show that Republican (Jacobs and Carmichael 2001; Stucky et al. 2005; Western 2006) or conservative political strength (Sutton 2000) led to severe criminal justice outcomes. Because capital punishment has been an important issue in many state political campaigns (Constanzo 1997) and because Jacobs and Carmichael (2002) find that this punishment is likely to be legal in states with the strongest Republican parties, we expect that greater Republican political strength in a state should increase execution probabilities.

Republican campaigns for the presidency have relied on and probably accentuated (Beckett 1997) mass perceptions about the links between purportedly venal underclass life styles and lawlessness. Findings show that votes for the first of these presidents who successfully exploited public views about the linkages between race and crime (Nixon in 1968) help explain how quickly states relegalized capital punishment after the 1976 court decisions that

\footnotetext{
${ }^{4}$ A participant described Nixon's 1968 campaign: "We'll go after the racists. That subliminal appeal to the anti-black voter was always present in Nixon's statements and speeches" (Ehrlichman 1982:233). Other vivid examples occurred in the 1988 Bush campaign against Dukakis. Republicans ran an advertisement declaring, " "Dukakis not only opposed the death penalty, he allowed first-degree murderers to have weekend passes from prison.'. . . [as the] clearly black [offender] —Willie Horton stared dully into the camera." They next released an advertisement featuring a victim. " Mike Dukakis and Willie Horton changed our lives forever ... Horton broke into our home. For twelve hours, I was beaten, slashed, and terrorized. My wife Angie was brutally raped"" (Carter 1996:76-77). This emphasis did not abate. In a House debate in 1994 "29 Republican[s] . . spoke derisively about midnight basketball ... characterizing the program as "hugs for thugs" (Hurwitz and Peffley 2005:99-100).
} 
forced changes in these statutes (Jacobs and Carmichael 2002). Incarceration rates also were higher after more voters supported a Republican law and order presidential candidate (Weidner and Frase 2003). Hence: Death row inmates should be less likely to avoid the death chamber in states in which more voters support Republican presidential candidates because prosecutors, appellate justices, and governors will face stronger pressures to allow executions in these jurisdictions.

\section{ADDitional CoNTROLS}

Murder is the most threatening crime. Execution probabilities therefore should be greater in states with higher murder rates. Following Durkheim's emphasis on the determinants of restitutive law, states with a larger and more diverse population and an enhanced division of labor should not be as likely to use this most severe punishment. This perspective also suggests that solidarity should matter. Migration interferes with social cohesion. Outsiders inspire hostility and fear, but their absence strengthens bonds and intragroup empathetic feelings (Hale 1996). Citizens in states with few outsiders therefore should not be as willing to support executions. This factor accounts for the legality of the death penalty (Jacobs and Carmichael 2002), so executions should be less likely when most residents were born in the states where they now live.

Research on imprisonment has focused on the Marxist view that punishment is used to control the supply of labor (Rusche and Kirchheimer 1939). Many researchers have assessed the link between unemployment and incarceration, but the results are mixed. A review (Chiricos and Delone 1992) shows that about 60 percent of the 147 associations between unemployment and imprisonments are significant. Despite such mixed results, we expect that high joblessness will enhance execution probabilities because the prosperous may view the unemployed as a threat or because high unemployment enhances resentments against criminals and accentuates demands for harsh sanctions. Yet the unemployment rate may have to reach a threshold before it matters, so we test a nonlinear relationship between this variable and execution probabilities. Primarily as a result of the multiple state and federal appeals, expensive expert testimony, and the other costs required for due process in decisions that may end a life, executions are far more expensive than alternatives such as life imprisonment. States with a superior tax base should be more likely to use this expensive punishment. Finally, to see if the unique arrangements in the South influence death row outcomes, we also control for this region.

\section{METHODS}

\section{ESTIMATION}

Our aim is to discover how offender attributes and the political and social characteristics of the states affect post-sentencing execution likelihoods. To test these hypotheses, we use an event history approach. This procedure provides a remedy for the censoring that occurs because offenders face different execution risks. Some offenders remained on death row after 2001, so this right-censored group was in danger of being executed after the end of the observation period. The other right-censoring occurs when offenders were removed from death row largely as a result of successful appeals. Event history analysis uses the information from cases with incomplete duration who were not executed to avoid the bias that would occur if these censored cases were not included. ${ }^{5}$ We employ discrete-time logit models to predict execution probabilities. Our first model will assess the influence of individual factors. This model takes the form:

$$
\log \left(\frac{P_{i j t}}{1-P_{i j t}}\right)=\alpha_{t d}+\sum_{m=1}^{M} \beta_{m} X_{m i}
$$

where $P_{i j t}$ is the conditional probability of execution for death row offender $i$ in state $j$ at time

\footnotetext{
${ }^{5}$ Because event history analysis takes advantage of all available information, we include death row offenders near the end of the analysis period although such offenders are not as likely to be executed. Offenders still on death row are right-censored regardless of how long they have been on death row, but our estimation approach will not be biased by this or other forms of censoring. Note that selection biases should not be problematic because we only explain what happens to offenders sentenced to death. We make no claims about whether those who received a less severe punishment than death would have different likelihoods of being executed if they had been sentenced to death.
} 
$t$ given that the execution has not already occurred to that individual prior to time $t . t$ is years from death sentence. The log odds of execution at time $t$ is a function of a set of time-constant covariates as well as a set of temporal dummies $(t d)$ to account for time dependence $\left(\alpha_{t d}\right){ }^{6}$ The individual level covariates entered in this model include offender race, ethnicity, gender, prior convictions, and victim race. The models also include interactions between offender and victim race. We assess the explanatory power of state-level contextual effects by using variables such as the percentage of a state's vote for Republican candidates in timevarying form. The subsequent and more exhaustive models therefore take the following form:

$$
\begin{gathered}
\log \left(\frac{P_{i j t}}{1-P_{i j t}}\right)= \\
\alpha_{t d}+\sum_{m=1}^{M} \beta_{m} X_{m i}+\sum_{n=1}^{N} \beta_{n} X_{n j(t-1)}
\end{gathered}
$$

where the conditional probability of execution at time $t$ is a function of a set of individual condemned prisoner factors as well as state characteristics at time $t-1$. Death row offenders may be treated similarly within a state with the same death penalty provisions and the same officials deciding appeals. To adjust for this possible departure from statistical independence, we report z-values corrected for within-state correlated errors with a cluster procedure (Rogers 1993).

\section{SAMPLE}

Most offender information was taken from

\footnotetext{
${ }^{6}$ Because execution risk is small in the first 12 years after a death sentence, we combine these years into one period and use it as the reference group. We then create three additional dummy variables: the first is coded 1 for periods since death sentence between 13 and 20 years, the second between 21 and 23 years, and the third from year 24 on death row and later. This categorization captures the distribution of execution likelihoods as this distribution has a long flat tail to the left resulting from low initial risks and an inverted-U shaped distribuion thereafter. To discover if this categorization is unrepresentative, we created alternative codes for death row years beyond 12 . The significance test results and the theoretical implications persist when we reestimate the models with these alternatives.
}

(ICPSR study 3958) "Capital Punishment in the United States" (CPUS) from 1973 to 2002 (this source is limited to those years). This source gives state, date of removal from death row, and reasons for removal, but it does not contain data on victim race. For all offenders who were executed, race of the victim, offender race, state, and execution date are available from the Death Penalty Information Center. ${ }^{7}$ To obtain victim race we merged this data into the CPUS file by matching execution date and race of executed offenders. ${ }^{8}$

To obtain race of victim for former death row offenders removed from death row before execution or for offenders still on death row, we had to use another source. The Supplemental Homicide Reports (SHR) contain information on offense date, victim race, offender race, and age. We obtain victim race by matching SHR data with offender data from state correction department records by first using date of offense, and then offender race and age, but only 16 states could or would provide offense date. We merge the offender data with the CPUS data using date of sentence, offender race, and age. This matching process yields victim race for 1,012 current and former death row offenders who were not executed in 16 states. To capture the effects of this explanatory variable, the analysis must be restricted to 16 states, but these states are selected by a presumably random process based on whether a state provides date of offense - an administrative decision inde-

${ }^{7}$ This Web site is www.deathpenaltyinfo.org. Although the Supreme Court's 1972 Furman decision made executions unconstitutional, Furman left open the possibility of a constitutional death penalty. Many death penalty states therefore maintained their death row populations and altered their statutes. In 1976 in Gregg and other cases the Court declared some modified death penalty statutes constitutional (Paternoster 1991; Zimring and Hawkins 1986). The data for a plausible study of death row outcomes before 1973 apparently do not exist.

${ }^{8}$ Since 1973, 768 of the 820 offenders executed were matched. Data inconsistencies in these two sources explain the modest unmatched remainder. States analyzed are: Arizona, California, Delaware, Florida, Georgia, Illinois, Kansas, Kentucky, Maryland, Missouri, New Jersey, Ohio, Tennessee, Texas, Virginia, and Washington. 
pendent of the state or offender characteristics at issue. ${ }^{9}$

We therefore have information on victim race for all executed offenders and for about 28 percent of current or former death row offenders in these 16 states who were not executed. Although the execution rate from our sample is much higher than the equivalent rate in the CPUS data, such disparate rates should not bias our multivariate results. Our goal is to discover which explanatory variables affect execution rates. We are interested in how relative execution risks shift based on, for example, the murder of a white instead of a nonwhite. Because we include all executed offenders in these states, but only a fraction of death row offenders who were not executed, our sample design is equivalent to a response-based sample design. Such a design uses all events that occur in a specified time period, but samples individuals who are at risk of experiencing the event but did not (Prentice and Pyke 1979). To analyze a response-based sample, Xie and Manski (1989) propose a weighted maximum likelihood estimator for a logit analysis. Xie and Manski demonstrate that estimates from a responsebased sample behave asymptotically with no bias and with little loss in efficiency. We apply this weighted maximum likelihood estimator in our logit model. Following Xie and Manski (1989), we define a weight variable that equals

$$
w t=\frac{q_{p}}{f_{p}}
$$

where if $p=1, q_{p}$ is the proportion executed from the CPUS sample and $f_{p}$ is the propor-

\footnotetext{
${ }^{9}$ Included states exhibit considerable variation in execution probabilities. Most but not all of the missing death penalty states are small with few at risk of execution. Two exceptions are North Carolina and Pennsylvania, but the corrections departments in these and the other missing states with death row populations would or could not provide offense dates, so the effects of victim race are not analyzed in these states. The funds from a generous grant were exhausted by the matching process we had to use to obtain data on victim race. We therefore cannot employ costly supplemental data sources such as newspaper accounts, local prosecutor records (if any exist), or make detailed appraisal of this process in particular death penalty states.
}

tion executed from our sample; if $p=0, q_{p}$ is the proportion not executed in the CPUS sample and $f_{p}$ is the proportion not executed in our sample. ${ }^{10}$

The selection procedures we use are likely to produce a random sample because our selection method depends on between data source matches. This assumption that our estimates of explanatory effects will be unbiased is corroborated by the results in Table 1 showing between sample contrasts. Most between sample offender attributes are extremely similar. Although Hispanics are underrepresented and whites are overrepresented in our sample, this bias is eliminated by including offender race and ethnicity in all analyses. Table 1 shows a total of 4,145 $(3,597+548)$ death row offenders between 1973 and 2002 in 16 states from the CPUS data, and 13.2 percent were executed $(548 / 4,145)$. In comparison to their proportion in the population, disproportionately more African Americans and Hispanics were on death row. Of those executed, slightly more were white. An overwhelming majority of death row offenders were male (98 percent); and even higher proportions of males were executed (99.3 percent). Absent controls, death row offenders with prior conviction records faced a higher chance of execution than those with no prior conviction. Among current or former death row offenders, two-thirds killed a white, but among the executed offenders, four-fifths killed a white. The multivariate analyses will show if victim race interacts with race of offender to alter execution likelihoods with other relevant factors held constant.

Finally, because the proportion of Asian and Native American death row offenders is too modest to produce statistically significant results, these offenders are excluded

\footnotetext{
${ }^{10}$ Weighted maximum likelihood estimates of a logit model make response-based samples behave asymptotically as if they were random (Manski and Lerman 1977). This method does not require that researchers select the best estimator. Even if the best estimator is probit rather than logit, Xie and Manski (1989) use Monte Carlo simulations to show that the weighted maximum likelihood logit estimator gives good results as long as response-based samples are larger than 1,000 as ours is.
} 
Table 1. Percentage Distributions of Offender Characteristics in 16 States by Sample ${ }^{\mathrm{a}}$

\begin{tabular}{|c|c|c|c|c|}
\hline & \multicolumn{2}{|c|}{ Total CPUS Sample } & \multicolumn{2}{|c|}{$\begin{array}{l}\text { Sample in Which Race } \\
\text { of Victim is Available }\end{array}$} \\
\hline & Not Executed & Executed & Not Executed & Executed \\
\hline & 3,597 & 548 & 1,012 & 548 \\
\hline \multicolumn{5}{|l|}{ Race (Percent) } \\
\hline White & 48.1 & 55.5 & 53.6 & 55.5 \\
\hline Black & 39.8 & 34.9 & 40.1 & 34.9 \\
\hline Hispanic & 12.1 & 9.7 & 6.2 & 9.7 \\
\hline \multicolumn{5}{|l|}{ Sex } \\
\hline Percent Male ${ }^{\mathrm{b}}$ & 98.3 & 99.3 & 98.0 & 99.3 \\
\hline \multicolumn{5}{|c|}{ Marital Status at Offense } \\
\hline Percent Married ${ }^{\mathrm{b}}$ & 24.0 & 30.8 & 21.2 & 30.8 \\
\hline \multicolumn{5}{|c|}{ College Education at Offense } \\
\hline Percent Yes ${ }^{\mathrm{b}}$ & 7.6 & 7.7 & 10.0 & 7.7 \\
\hline \multicolumn{5}{|l|}{ Prior Convictions } \\
\hline Percent Yes ${ }^{b}$ & 59.4 & 68.2 & 59.5 & 68.2 \\
\hline \multicolumn{5}{|c|}{ Race of the Victim (Percent) } \\
\hline White & & & 66.5 & 80.3 \\
\hline Nonwhite & & & 33.5 & 19.7 \\
\hline
\end{tabular}

a Marital status and college education at offense cannot be used in the logit regressions because too many missing values are present; we provide their distributions to better compare samples that do not include and include race of victim.

${ }^{\mathrm{b}}$ These percentages plus the omitted category for each variable sum to 100 percent.

from our analyses. We also exclude offenders who died on death row for reasons other than an execution, but these decisions have no discernable effects on the results. ${ }^{11}$ We therefore analyze outcomes experienced by 1,560 postFurman death row offenders in 16 states from 1973 to 2002. The corrections we use-that are grounded in the econometric literature on how such samples can be analyzed to provide accurate findings-should give unbiased and consistent estimates of the determinants of executions. This is so even though our sample includes all offenders who were executed, but only about 28 percent of those who were not executed in these 16 states.

${ }^{11}$ We eliminated 179 offenders from the sample because they died on death row before execution; 118 Native Americans and 34 Asians or Pacific Islanders also were eliminated leaving a total of 1,560 offenders. In analyses (not shown) we find that these exclusions do not affect the reported results. Deficiencies in the data made efforts to code race of victim in the few instances when there were multiple victims too speculative, so most of these cases were omitted.

\section{MODEL SPECIFICATION AND EXPLANATORY VARIABLE MEASUREMENT}

One general specification of the discrete time logit model that predicts the log of execution odds for death row offender $i$ in state $j$ at time $t$ is:

$$
\begin{aligned}
& \text { Log EXECUTION ODDS } \text { Eij(t) }= \\
& \text { (td DURATION DUMMIES) + } \\
& \mathbf{b}_{1} \text { BLACK }_{\mathrm{ij}}+\mathbf{b}_{2} \text { HISPANIC }_{\mathrm{ij}}+ \\
& \mathbf{b}_{3} \text { VWHITE }_{\mathrm{ij}}+\mathbf{b}_{4} \text { BLACK }_{\mathrm{ij}} \times \\
& \text { VWHITE } \left._{\mathrm{ij}}\right)+\mathbf{b}_{5}\left(\text { HISPANIC }_{\mathrm{ij}} \times\right. \\
& \text { VWHITE } \left._{i j}\right)+\mathbf{b}_{6} \text { MALE }_{\mathrm{ij}}+ \\
& \mathbf{b}_{7} \text { PRIOR }_{\mathrm{ij}}+\mathbf{b}_{8} \% \mathrm{BLK}_{\mathrm{j}(\mathrm{t}-1)}+ \\
& \mathbf{b}_{9} \% \mathrm{BLK} 2_{\mathrm{j}(\mathrm{t}-1)}+ \\
& \mathbf{b}_{10} \% \mathrm{HISP}_{\mathrm{j}(\mathrm{t}-1)}^{3}+\mathbf{b}_{11} \mathrm{POP}_{\mathrm{j}(\mathrm{t}-1)}+ \\
& \mathbf{b}_{12} \text { MURDRT }_{\mathrm{j}(\mathrm{t}-1)}+\mathbf{b}_{13} \text { BORNINST }_{\mathrm{j}(\mathrm{t}-1)}+ \\
& \mathbf{b}_{14} \text { IDEOLOGY }_{\mathrm{j}(\mathrm{t}-1)}+\mathbf{b}_{15} \% \text { PPRSVOTE }_{\mathrm{j}(\mathrm{t}-1)}+ \\
& \mathbf{b}_{16} \text { RLMEDINC }_{\mathrm{j}(\mathrm{t}-1)}+\mathbf{b}_{17} \% \mathrm{UNEMP}_{\mathrm{j}(\mathrm{t}-1)}+ \\
& \mathbf{b}_{18} \% \text { UNEMP }_{\mathrm{j}(\mathrm{t}-1)}+\mathbf{b}_{19} \text { YEAR92PLUS }_{\mathrm{j}}+ \\
& \mathbf{b}_{20} \mathrm{STH}_{\mathrm{j}}
\end{aligned}
$$

where all explanatory variables are defined below. ${ }^{12}$

\footnotetext{
12 We use exhaustive models. According to Johnston (1984), "It is more serious to omit relevant
} 
INDIVIDUAL EFFECTS. We create two dummy variables for minority offenders: the first equals 1 if an offender is African American (BLACK), the second equals 1 if an offender is Hispanic (HISPANIC), and both dummies are set equal to 0 if the condition in question is not true. Another dummy variable is coded 1 only if the victim is white (VWHITE). We next create two interaction terms: the first (BLACK $\times$ VWHITE) is equal to the dummy variable coded 1 for an African American offender times the dummy variable coded 1 for a white victim; the second (HISPANIC $\times$ VWHITE) is equal to the dummy variable coded 1 for an Hispanic offender times the dummy variable coded 1 for a white victim. Additional individual effects are held constant with a dummy variable coded 1 if a death row inmate is male (MALE) and another coded 1 if a death row inmate has prior convictions (PRIOR). ${ }^{13}$

Contextual efFects. We measure racial threat effects with the percentage of African Americans (\%BLK) and the percentage of

variables than to include irrelevant variables since in the former case the coefficients will be biased, the disturbance variance overestimated, and conventional inference procedures rendered invalid, while in the latter case the coefficients will be unbiased, the disturbance variance properly estimated, and the inference procedures properly estimated. This constitutes a fairly strong case for including rather than excluding relevant variables in equations. There is, however, a qualification. Adding extra variables, be they relevant or irrelevant, will lower the precision of estimation of the relevant coefficients" (p. 262). Hence our comprehensive models should produce more accurate point estimates but the significance tests will be relatively conservative.

13 Although we cannot introduce a control for offense severity because information is not available, a legal requirement probably makes such a control unnecessary. In the Gregg case that relegalized capital punishment, the Court held that jurors can sentence offenders to death only if they deem the crime to be sufficiently horrific. Aggravating criteria stipulated by legislatures that jurors must consider when making this judgment include the killing of multiple victims, murdering a child, or homicides that involve deliberate torture (Paternoster 1991). Such prerequisites probably create a more precise control for offense severity than the alternatives used in studies that assess sentencing for non-capital crimes.
Hispanic residents (\%HISP) in each state, but in contrast to all other contextual variables, the percentage of Hispanics in the states is unavailable in the non-census years before 1990. We therefore use decennial census figures in the five years after a census and figures from the next census in the next five years before 1990; after 1990 this variable is time varying by year (the results persist if we use yearly linear interpolations to estimate these missing values). ${ }^{14}$ To capture nonlinear quadratic relationships, both minority threat variables are entered in untransformed and squared form. All state-level variables, save the percentage of Republican votes for president and Hispanics (which time vary by four or five years), are time-varying by year. Following convention in studies of public policy, the yearly time-varying explanatory variables are lagged by a year because their effects should not be instantaneous.

Theory, however, suggests that Hispanic presence should have a nonlinear relationship with execution probabilities that becomes increasingly stronger as this indicator reaches extreme values, yet there is no reason to think this association should shift direction. Higher percentages of Hispanics, for example, may well produce increasingly greater execution probabilities, but it is difficult to see how growth from a low to a somewhat higher percentage of Hispanics could lead to reductions in execution probabilities. When a priori considerations suggest that such nonlinear relationships that should not change direction are present, power transformations are most appropriate (Cohen et al. 2003:225-54). Threat theory thus suggests that a single exponential transformation will be best. To avoid iterative searches for the best exponent and overfitting, we cube the percentage of Hispanics. This power transformation is somewhat unconventional in sociology (but not in psychology). To provide comparisons and reassure the reader, we present otherwise identical models with and without this transformation.

We assess the influence of the division of labor with population (POP). Following Jacobs and Carmichael (2002), who find that this meas-

\footnotetext{
14 The great majority of the death row outcomes we study occurred after 1990 when the percentage of Hispanics in the states is calculated with yearly data.
} 
ure of outsider presence explains whether a state has a legal death penalty, outsiders are measured with a dummy coded 1 if over 75 percent of a state's population was born in-state (BORNINST). We assess partisanship with the percentage of a state's vote for the Republican candidate in the last presidential election (PPRSVOTE). The threat from higher murder rates is gauged by murder rates provided by the Uniform Crime Reports.

Berry and colleagues (1998) view mass ideologies (IDEOLOGY) as the mean on a liberal-conservative continuum. They identify the ideological position of each member of Congress using interest-group ratings (Americans for Democratic Action, Committee on Political Education) of a representative's voting record and then estimate mass ideology in each congressional district with this score for the district's incumbent and with an estimated score for the incumbent's challenger in the last election. Incumbent ideology scores are combined with estimated challenger ideology scores weighted by district election results to capture district ideologies. Berry and colleagues calculate state-level scores on liberalism-conservatism with the mean of these within-state congressional district scores. We analyze the most recent version of this index, which gauges congressional votes until 2003 and adds a few corrections to the values first published in 1998 . The most liberal states receive the highest scores, so the coefficients on this variable should be negative. ${ }^{15}$

We measure the tax base and a state's ability to support this costly punishment with real median household income (RLMEDINC). We

\footnotetext{
${ }^{15}$ This index has face validity. From 1972 to 2002 Rhode Island and Massachusetts tied for second as the most liberal states. But the sole Vermont representative - who probably was the only member of Congress who claimed to be a socialist in this period - earned the highest liberalism score. Mississippi in 1972 had the most conservative score followed by Virginia in 1974. Specialists have accepted the use of roll-call, vote-based indexes to identify ideology (Fowler 1982; Poole and Rosenthal 2000). Rankings by Americans for Democratic Action (ADA) and the AFL-CIO's Committee on Political Education (COPE) are the most widely used and have withstood considerable scrutiny (Herrera, Epperlein, and Smith 1995; Shaffer 1989).
}

capture joblessness with the percentage of unemployed (\%UNEMP). Because this factor may have a nonlinear relationship, we include its square. We also include a dummy variable coded 1 (YEAR92PLUS) for years after 1992 when execution frequencies increased and a dummy variable coded 1 for southern states (STH). We use one-tailed tests because theoretically based predictions about sign have been stipulated. ${ }^{16}$

\section{ANALYSES \\ DESCRIPTIVE STATISTICS AND Multivariate Models of EXECUTION Probabilities}

INITIAL ANALYSES. Figure 1 shows the distribution of death row outcomes during the years in question and Table 2 shows the predicted signs, means, and standard deviations. In Table 3 we begin the multivariate analyses by restricting the first model to individual explanatory factors to show contrasts with subsequent models that include contextual effects. Recall that two dummy variables are set equal to 1 if offenders are African American or Hispanic. A third is set equal to 1 if the victim is white, and this victim variable is interacted with the two minority offender variables to create two interaction terms. The coefficients on these two product terms capture what happens to either African American or Hispanic offenders who killed whites (all necessary main effects are included). A sixth dummy variable is set equal to 1 if a condemned offender is male, while the last is equal to 1 if an offender has prior convictions. In Model 2 we begin to add contextual variables by entering the percentage of African American and Hispanic residents in quadratic form. To assess division of labor effects, population is included as well. We add the percentage born in-

\footnotetext{
${ }^{16}$ Despite repeated attempts we have not located information on the partisanship of state appellate court justices. In almost all states, one appellate court handles each level of state death row appeals, so variation in offender outcomes probably cannot be attributed to within state appellate court differences. Data on factors such as offender demeanor, their behavior in prison, offense characteristics other than those measured, and additional information on offender appeals unfortunately are not available.
} 


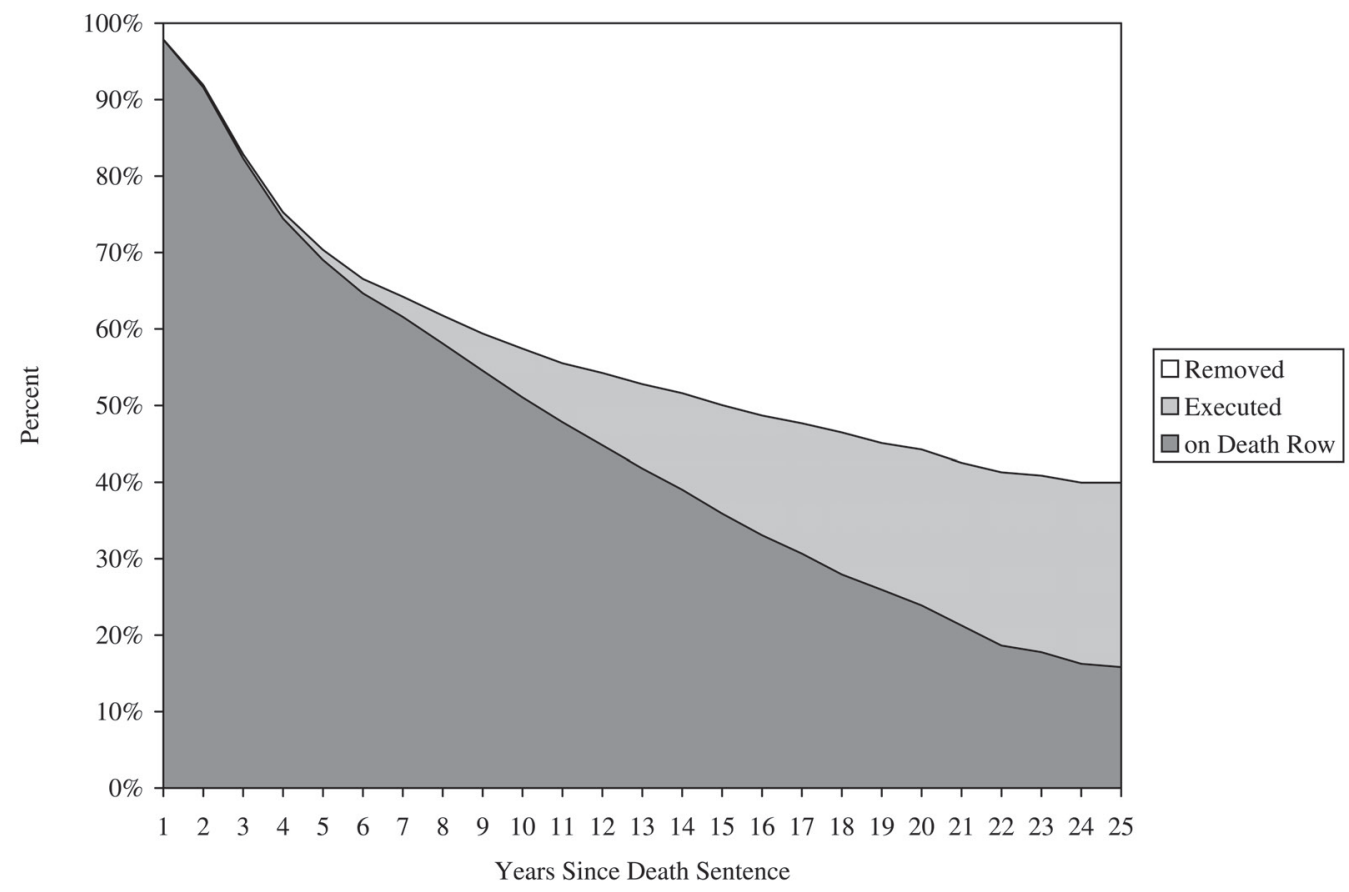

Figure 1. Three Death Row Outcomes in 16 States by Years After Death Sentence

state and a quadratic test of the effects of unemployment in Model 3.

The results in Model 1 show that several individual offender attributes contribute to execu- tion probabilities. The coefficient on the first main effect shows that African American offenders whose victims are not white are less likely to be executed. But the coefficients on the two

Table 2. Predicted Signs, Means, and Standard Deviations

\begin{tabular}{lrrr}
\hline \hline Variable & Predicted Sign & Mean & SD \\
\hline 1 if Executed & & .010 & .099 \\
1 if Black Offender & + & .390 & .488 \\
1 if Hispanic Offender & + & .068 & .251 \\
1 if White Victim & + & .710 & .454 \\
1 if Black $\times 1$ if White Victim & + & .161 & .367 \\
1 if Hispanic $\times 1$ if White Victim & + & .036 & .187 \\
1 if Male & + & .986 & .116 \\
1 if Prior Conviction & + & .650 & .477 \\
Percent Black & + & 12.772 & 5.331 \\
Percent Black ${ }^{2}$ & - & 191.548 & 171.170 \\
Percent Hispanic & 0 & 15.212 & 11.189 \\
Percent Hispanic $3 / 10,000$ & + & .943 & 1.169 \\
Population/1,000,000 & - & 13.751 & 8.021 \\
if Percent Born in State $>$ 75 Percent & - & .225 & .417 \\
Murder Rate per 100,000 & + & 9.332 & 2.906 \\
Citizen Ideology & - & 43.608 & 9.149 \\
Percent Republican Vote for President & + & 48.695 & 9.330 \\
Real Median Household Income/100 & + & 366.480 & 47.638 \\
Percent Unemployed & + & 6.051 & 1.532 \\
if Southern State & + & .528 & .499 \\
\hline
\end{tabular}

Note: Weighted by 16,361 offender-years from 16 sampled states. 
Table 3. Post-Capital Sentencing Determinants of Executions Estimated with Discrete-Time Logit

\begin{tabular}{|c|c|c|c|c|c|c|}
\hline \multirow[b]{2}{*}{ Explanatory Variables } & \multicolumn{2}{|c|}{ Model 1} & \multicolumn{2}{|c|}{ Model 2} & \multicolumn{2}{|c|}{ Model 3} \\
\hline & Coef. & SE & Coef. & SE & Coef. & SE \\
\hline \multicolumn{7}{|l|}{ Individual Effects } \\
\hline 1 if Black Offender & $-1.015^{* * *}$ & .349 & $-.761 * * *$ & .220 & $-.758 * * *$ & .215 \\
\hline 1 if Hispanic Offender & -.375 & .465 & .131 & .228 & .102 & .238 \\
\hline 1 if White Victim & -.348 & .258 & -.067 & .230 & -.157 & .219 \\
\hline 1 if Black Off. $\times 1$ if White Victim & $1.394 * * *$ & .371 & $.898 * *$ & .322 & $1.042 * * *$ & .337 \\
\hline 1 if Hispanic Off. $\times 1$ if White Victim & $1.130 * *$ & .422 & .332 & .255 & $.449 *$ & .257 \\
\hline 1 if Male & .458 & .499 & $.907 *$ & .545 & .870 & .539 \\
\hline 1 if Prior Conviction & .082 & .130 & .134 & .103 & .123 & .086 \\
\hline \multicolumn{7}{|l|}{ Contextual Effects } \\
\hline Percent Black & - & - & $.443 * * *$ & .106 & $.423 * * *$ & .077 \\
\hline Percent Black ${ }^{2}$ & - & - & $-.011 * * *$ & .003 & $-.012 * * *$ & .002 \\
\hline Percent Hispanic & - & - & -.052 & .058 & -.036 & .054 \\
\hline Percent Hispanic ${ }^{2}$ & - & - & $.005^{* * *}$ & .001 & $.003 * *$ & .001 \\
\hline Population/1,000,000 & - & - & $-.149 * * *$ & .040 & $-.100 * * *$ & .029 \\
\hline 1 if Percent Born in State $>75$ Percent & - & - & - & - & $-1.813 * * *$ & .322 \\
\hline Percent Unemployed & - & - & - & - & $-1.144 * *$ & .392 \\
\hline Percent Unemployed ${ }^{2}$ & - & - & - & - & $.069 * *$ & .027 \\
\hline Constant & $-5.101 * * *$ & .633 & $-8.556^{* * *}$ & 1.118 & $4.093 * * *$ & 1.258 \\
\hline Log Likelihood & \multicolumn{2}{|c|}{$-873.3 * * *$} & \multicolumn{2}{|c|}{$-816.6^{* * *}$} & \multicolumn{2}{|c|}{$-793.7 * * *$} \\
\hline BIC Statistic & \multicolumn{2}{|c|}{1853.4} & \multicolumn{2}{|c|}{1778.8} & \multicolumn{2}{|c|}{1732.8} \\
\hline
\end{tabular}

Notes: $\mathrm{N}=1,560$ offenders and 16,361 offender-years from 16 states; state-level cluster corrected standard errors; coefficients on offender-year dummies not shown.

$* p \leq .05 ; * * \leq .01 ; * * * p \leq .001$ (one-tailed tests except for intercept).

interaction terms suggest that African Americans or Hispanics found guilty of killing members of the majority race face a greater likelihood of this punishment (we defer discussing significance tests on contrasts between the coefficients on individual variables until discussion of the best model). If they persist, these last findings are particularly important as they suggest that the extra-legal attribute with the most powerful effects on death sentences accounts for postdeath sentence execution probabilities as well.

In Model 2 we add five contextual variables to the individual determinants in the first model. Although these additions increase model explanatory power as the BIC statistic falls sharply, the coefficients on the interaction terms that assess execution probabilities for minorities who kill whites remain significant. We again find that African Americans convicted of murdering nonwhites are less likely to be executed, but execution probabilities remain higher for African Americans who kill a white. The contextual results show that execution probabilities are greater in states with more African Americans until a threshold in this proportion is reached (we also defer reporting this inflection point until the presentation of the best model). Although the percentage of Hispanic residents has no effect, this ethnic threat variable in squared form enhances execution probabilities. Additional findings show that states with larger populations and a greater division of labor are not as likely to execute. After we add the unemployment rate and its square together with the percentage born in-state, these initial results suggest that unemployment rates influence execution probabilities, but this penalty is less likely in states with few outsiders.

COMPREHENSIVE MODELS. Yet other accounts may matter. In Model 4 of Table 4, we add state murder rates, citizen ideology, votes for Republican presidential candidates, real median income, and a dummy variable for years after 1992 when the number of executions expanded. Model 5 is identical to Model 4, but we replace the quadratic Hispanic threat specification with the cubic power transformation. Model 6 only differs from Model 5 because a 
Table 4. Post-Capital Sentencing Determinants of Executions Estimated with Discrete-Time Logit

\begin{tabular}{|c|c|c|c|c|c|c|}
\hline \multirow[b]{2}{*}{ Explanatory Variables } & \multicolumn{2}{|c|}{ Model 4} & \multicolumn{2}{|c|}{ Model 5} & \multicolumn{2}{|c|}{ Model 6} \\
\hline & Coef. & SE & Coef. & $\mathrm{SE}$ & Coef. & SE \\
\hline \multicolumn{7}{|l|}{ Individual Effects } \\
\hline 1 if Black Offender & $-.737 * * *$ & .233 & $-.744 * * *$ & .234 & $-.764 * * *$ & .231 \\
\hline 1 if Hispanic Offender & .108 & .248 & .107 & .248 & .099 & .253 \\
\hline 1 if White Victim & -.141 & .202 & -.144 & .202 & -.158 & .200 \\
\hline 1 if Black Off. $\times 1$ if White Victim & $1.007 * *$ & .339 & $1.011 * *$ & .342 & $1.033^{* * *}$ & .334 \\
\hline 1 if Hispanic Off. $\times 1$ if White Victim & $.429 *$ & .256 & $.437 *$ & .263 & $.454^{*}$ & .269 \\
\hline 1 if Male & .845 & .527 & .852 & .531 & .848 & .530 \\
\hline 1 if Prior Conviction & $.118^{*}$ & .069 & $.119^{*}$ & .073 & .121 & .075 \\
\hline \multicolumn{7}{|l|}{ Contextual Effects } \\
\hline Percent Black & $.450 * * *$ & .066 & $.439 * * *$ & .065 & $.479 * * *$ & .113 \\
\hline Percent Black ${ }^{2}$ & $-.014 * * *$ & .002 & $-.014 * * *$ & .002 & $-.014 * * *$ & .003 \\
\hline Percent Hispanic & -.019 & .068 & - & - & - & - \\
\hline Percent Hispanic ${ }^{2}$ & .002 & .002 & - & - & - & - \\
\hline Percent Hispanic $3 / 10,000$ & - & - & $.533 * * *$ & .109 & $.569 * * *$ & .134 \\
\hline Population $/ 1,000,000$ & $-.099 * * *$ & .025 & $-.099 * * *$ & .027 & $-.099 * * *$ & .026 \\
\hline 1 if Percent Born in State $>75$ Percent & $-2.000 * * *$ & .265 & $-1.998 * * *$ & .284 & $-2.089 * * *$ & .397 \\
\hline Murder Rate & $.088^{*}$ & .045 & $.102 * *$ & .043 & $.102 *$ & .045 \\
\hline Citizen Ideology & $-.030 * *$ & .011 & $-.029 * *$ & .011 & $-.033 * * *$ & .009 \\
\hline Percent Republican Vote for President & $.048 * * *$ & .011 & $.048 * * *$ & .012 & $.052 * * *$ & .010 \\
\hline Real Median Household Income /100 & $.010 * * *$ & .003 & $.010 * * *$ & .003 & $.009 * *$ & .003 \\
\hline Percent Unemployed & -.749 & .463 & -.778 & .493 & -.783 & .500 \\
\hline Percent Unemployed ${ }^{2}$ & .050 & .033 & .052 & .035 & .052 & .036 \\
\hline 1 if after 1992 & $1.597 * * *$ & .307 & $1.602 * * *$ & .316 & $1.635^{* * *}$ & .302 \\
\hline 1 if Southern State & - & - & - & - & -.291 & .611 \\
\hline Constant & $-12.123^{* * *}$ & 2.268 & $-12.016^{* * *}$ & 1.951 & $-12.004 * * *$ & 1.966 \\
\hline Log Likelihood & \multicolumn{2}{|c|}{$-776.1 * * *$} & \multicolumn{2}{|c|}{$-775.6^{* * *}$} & \multicolumn{2}{|c|}{$-775.5^{* * *}$} \\
\hline BIC Statistic & \multicolumn{2}{|c|}{1697.7} & \multicolumn{2}{|c|}{1696.8} & \multicolumn{2}{|c|}{1696.5} \\
\hline
\end{tabular}

Notes: $\mathrm{N}=1,560$ offenders and 16,361 offender-years from 16 states; state-level cluster corrected standard errors; coefficients on offender-year dummies not shown.

$* p \leq .05 ; * * p \leq .01 ; * * * p \leq .001$ (one-tailed tests except for intercept).

control for state location in the South is added to the explanatory variables entered in Model 5.

The results in Model 4 show that the addition of political variables and the tax base measure increase model explanatory power as the BIC statistic again declines from its value in Model 3. The findings confirm other contextual expectations: liberal states are less likely to execute, but capital punishment likelihoods are higher in states where Republican presidential candidates received the most votes and where the tax base is substantial. These findings show that the murder rates have the expected positive relationship with executions, but the unemployment rates are no longer significant after the addition of contextual variables that assess state political environments. When we replace the quadratic Hispanic specification with the cubic power alternative in Model 5, all results persist, but the coefficient on Hispanic threat becomes significant.

A test of the significance of the difference between the absolute value of the coefficient on the black offender main effect and the coefficient on the interaction term that gauges execution likelihoods for blacks who kill whites shows that the interaction term coefficient is greater than its counterpart on the main effect (two-tailed $p=.038$ ). Other tests that gauge the statistical significance of contrasts reveal that the coefficient on the blacks who kill whites term is most substantial. For example, when we replace the condemned blacks main effect with the same variable for whites, we find identical significance test results again indicating that the coefficient on the black killings of whites interaction term is more substantial. Similar tests show that the coefficient on the 
black killings of whites interaction term is greater than the coefficient on the Hispanicwhite victim interaction term (two-tailed $p=$ .023). Finally, when we add the South in the last model, we find no noteworthy changes in the results.

We now can calculate the inflection point where the relationship between the percentage of African Americans and execution probabilities shifts from positive to negative. Again using coefficients from the best model (Model 5), we find that this change occurs after the percentage of African American residents reaches 16.2 or about the 86th percentile in the percentage of African American residents in these 16 states in this period. This result suggests that execution probabilities start to fall only after the potential African American vote reaches a rather substantial threshold. And odds ratios suggest that these effects are not weak. The exponentiated coefficient from Model 5 that gauges execution probabilities for African Americans convicted of killing a white is 2.75 . The odds ratio for African Americans who kill nonwhites is .476. The odds ratio for Hispanics convicted of killing a white is 1.55 . The size of some contextual effects are substantial as well: for example, the odds ratio for the percentage of blacks in these states is 1.55 and its counterpart on the cube of Hispanic presence is 1.70 .

AdDitional COnsiderations. Some death row inmates accept their sentences and try to stop all appeals. These "volunteers" are disproportionately white (Lofquist 2002). In states that rarely execute, a greater proportion of the few executed offenders are volunteers (Lofquist 2002), so a failure to control for this effect may bias the estimates. The data at hand do not let us identify such offenders, but we can discover if this effect matters because volunteers are executed with less delay. If those executed early differ sharply from those executed later, analyses limited to inmates executed later - or models restricted to offenders executed from 5 to 10 years after sentencing - should produce findings that differ, but they do not. The same variables are significant in each of these five restricted analyses (not shown but available on request). Such theoretically identical findings suggest that our inability to directly control for volunteers has not distorted the findings.
We find no evidence for additional interaction effects and these negative results persist when we assess cross-level interactions between individual and jurisdictional characteristics. This result is important for methodological reasons. Cross-level interaction significance tests are too optimistic if such tests are not estimated with an Hierarchical Linear Model (HLM) approach. Yet none of these interactions are significant when they are assessed with the nonHLM method we employ. Such cross-level effects therefore will not be uncovered if they are estimated with HLM because this estimator will produce larger estimates of the standard errors. The cluster adjustment we use to correct the standard errors for within state interdependencies therefore should suffice, as HLM will produce the same nonsignificant and redundant findings about cross-level interactions. ${ }^{17}$

We entered religious fundamentalism along with various measures of Republican governors and this party's strength in state legislatures, but these determinants had no effects (models not shown). We find no evidence that federal judge partisanship influences executions. ${ }^{18}$ To isolate the effects of otherwise omitted crossstate national political, social, or macroeconomic changes, we included dummies coded for

\footnotetext{
${ }^{17}$ For readers who prefer two-tailed significance tests even if theoretical justification for direction is provided, we list coefficients that reached the one- but not the two-tailed .05 level: in Table 3, the male offender variable in Model 2 is significant at the .05 one- but not the two-tailed threshold and the same is true for the Hispanics who killed whites interaction term in Model 3. In Table 4, each of the coefficients on the Hispanics convicted of killing a white interaction term are significant at the one- but not the twotailed level and the same generality holds for the coefficient on the prior conviction variable in Model 4.

${ }^{18}$ We gauged the degree to which the estimates are robust by dropping each of the 16 sampled states in analyses not shown. The implications persist but this dependent variable already was skewed. To avoid a logit model that could not be estimated after we removed a state with many executions and increased dependent variable skewness, we had to remove a few explanatory variables from some of these 16 equations. Only one of the 16 sampled death penalty states (Kansas, which had a tiny death row population) had no executions. The elimination of states with few executions had only tiny effects on the estimates.
} 
each year (models not shown). All explanatory variables that matter in Table 4 were significant in these models. Such results suggest that shifts in the national political or macroeconomic climate cannot account for these results. The models in Table 4 pass the link test for misspecification. These considerations provide added reasons to think that the most comprehensive models capture the primary determinants of death row outcomes. ${ }^{19}$

We nevertheless must acknowledge that we were forced to use advanced statistical techniques to overcome data limitations. Although there are good reasons to believe that the reported estimates are unbiased and consistent, superior data always are preferable to such statistical alternatives (for a forceful illustration, see Donohue and Wolfors 2005). In particular, we hope that subsequent researchers can obtain more exhaustive information on victim race and other considerations from additional death penalty states. Perhaps researchers with the resources and the time to achieve a better rapport with state correction agency officials who would not cooperate with our requests for data can produce superior findings about this issue by analyzing additional states.

\section{DISCUSSION}

\section{THE FINDINGS}

Possibly because offender prior convictions contribute to prosecutors' decisions to seek the death sentence and lead trial courts to support this request, we find weak and inconsistent evidence that this factor affects post-death sentence execution probabilities. The findings show that gender is nonsignificant, but the proportion

\footnotetext{
19 Attempts to use other diagnostic tests failed because these estimates are weighted. Tests conducted without the weights suggest that estimation problems are not present. No observation has a high leverage score, and there are only a few modest outliers. Estimate stability and a VIF analysis conducted on the state variables (without the squared terms) yields a maximum score 4.33. Both considerations suggest that collinearity is not present. Although we analyze 16 states, there are 480 state-years as all but two of our state-level variables are time-varying by year. Fewer case-years are common in pooled timeseries analysis.
}

of condemned women in our sample is tiny. Yet victim race clearly is the most important individual finding. The coefficients and the significance tests that gauge contrasts in the size of these point estimates show that blacks convicted of killing whites are more likely to be executed than other death row offenders. Such results do not contradict hypotheses that local prosecutors with an interest in protecting wellpublicized legal victories that should further their political careers make successful efforts to resist death row appeals. These findings also support a hypothesis that state justices do not ignore pressures to deny appellate relief to minority death row offenders who kill whites. But the findings suggest that African Americans on death row for killing nonwhites are less likely to be executed than other condemned prisoners.

The evidence corroborates hypotheses that Hispanics also face higher execution probabilities if their victims are white. Yet the odds ratios that gauge the strength of this Hispanic effect and the untransformed coefficients are significantly weaker than their counterparts that assess the strength of the black offender, white victim effect. Such contrasting results about the explanatory power of ethnic rather than racial effects should not be surprising in light of the fiercely divisive and violent conflicts about race throughout U.S. history (Myrdal 1944; Tocqueville 1948). Only a few states had substantial Hispanic populations before the 1990s. This ethnic group may have been too small in most death penalty states to be sufficiently threatening. Subsequent studies, however, may provide greater support for this ethnic threat account because the Hispanic population recently has expanded so rapidly.

The contextual results always show that minority proportions matter. Larger percentages of African American residents produce higher execution probabilities, but this effect becomes negative only after the proportion of African Americans reaches a relatively substantial threshold. The positive sign on the unsquared coefficient provides evidence for a racial threat account, but the negative sign on the squared percentage of African American residents suggests that execution probabilities respond to election pressures. The form of the nonlinear relationship between Hispanic proportions in a state and execution probabilities 
differs from the nonlinear association between African American presence and these probabilities. Probably because the proportion of Hispanics in all but a few states was so modest, the findings indicate that a growth in the percentage of Hispanics yields increasingly stronger execution probabilities without a reversal in the sign of this relationship.

Consistent with prior findings on the factors that produce a legal death penalty in the states (Jacobs and Carmichael 2002), the findings in this article suggest that jurisdictions with the most residents born in-state are less likely to use this ultimate punishment. This association probably is based on latent hostility to strangers (Hale 1996) and to a corresponding reluctance to invoke the ultimate penalty against people who are regarded as one's neighbors. A different aggregate finding supports another threat account, as the results show that execution probabilities are greater in states that have the highest murder rates.

Votes for Republican presidential candidates, who often run on law and order platforms, help explain execution likelihoods as well. Beckett's (1997) findings suggest that law and order campaign rhetoric magnifies the public salience of the crime issue. Successful law and order political campaigns therefore should produce greater support for the harshest punishment. The sensitizing effects of this rhetoric and the relative success of Republican law and order candidates in some jurisdictions - which almost certainly indicates considerable preexisting support for capital punishment-help explain why votes for Republican candidates provide such a robust explanation for executions. It is interesting that the presence of a Republican governor does not increase execution probabilities (results not shown), but this finding should not be surprising as this factor does not explain the legalization of capital punishment (Jacobs and Carmichael 2002). Governors must decide the final appeal before an execution. This awesome moral responsibility gives these political officials good reason to be ambivalent about this punishment (Jacobs and Carmichael 2002; Zimring and Hawkins 1986).

As theorists such as Garland (1990, 2001) and Savelsberg (1994) would expect, the explanatory power of political ideology suggests that political values contribute to the propensity to execute. When or where there is greater political support for liberal values, execution probabilities diminish. This result supports claims (Lakoff 1996) that support for the death penalty is one of the most important differences between liberals and conservatives. Finally, the results suggest that the affluent states that can better afford this costly punishment use it more often.

\section{WIDER IMPLICATIONS}

This analysis fills critical gaps in the sparse literature on the application of capital punishment. First, we gauged the effects of offender-victim racial contrasts and found that victim race is a strong determinant of executions. Until this study, and despite the empirical strength of victim race in trial-court studies about the death sentence process, apparently no research has gauged the explanatory power of this factor. In addition to the findings about theoretically important individual and legal factors, our data set lets us test environmental determinants that have been ignored in the literature. The findings suggest that these contextual omissions are unfortunate, as environmental accounts have substantial explanatory power in this and in other analyses that seek to explain criminal justice outcomes. Compared to the studies of the determinants of death sentences that are restricted to individual data from one or a few jurisdictions, this study's coverage is far greater as we assessed the effects of both individual and contextual accounts over a 30 -year period in a diverse set of multiple states.

Reviews of the related research on race and felony sentencing (Chiricos and Crawford 1995; Walker et al. 1996) suggest that substantial disagreement exists in this literature. These reviews both base their conclusions on results that appear in only a bare majority of the many available investigations. Almost all of the many studies that analyze trial court sentencing are based on offender samples from just one or only a few trial courts in a specific region. Yet since trial courts exist in diverse environments, inconsistent results can be expected. If each court study investigates death penalty sentences in just one or a few localities, and their political climates differ, it will be difficult to uncover general relationships, particularly because court environments have so much explanatory power 
(Helms and Jacobs 2002). The same reasoning holds for death penalty investigations. It follows that a study of executions in many states that assesses both contextual and individual factors should provide more accurate results than would analyses restricted to individual explanations in just one or only a few jurisdictions.

Another plausible explanation for these disagreements concerns the neglect of political effects in almost all of the studies of criminal justice system outcomes. As one might expect in light of the recent theoretical emphasis on the political nature of legal punishments (Chambliss 1994; Foucault 1977; Garland 1990, 2001) and the Republican party's tactical use of law and order appeals to covertly enhance voters' racial fears (see the quotes in note 4), these results show that executions increased after states awarded additional votes to Republican candidates. Yet increased electoral support for law and order Republicans who enthusiastically embrace the death penalty may be based on preexisting conservative values. But this alternative hypothesis is unlikely as votes for Republican presidential candidates account for executions after citizen ideology has been held constant. Such findings, of course, show that these supposedly objective and purely legal decisions about who will die are shaped by factors that should not be relevant.

These findings also confirm the racial politics perspective that provided the primary conceptual impetus for this research. In the homogeneous European democracies, predominant penal emphasis is on the reintegration of offenders into a solidaristic society administered by experts who are only distantly accountable to the voters (Savelsberg 1994; Whitman 2003). In the United States, however, the public's Manichean image of human nature, combined with a history of bitter racial conflict, has produced an exclusionary penal system. According to Wacquant (2000, 2001), the resilient divisions produced by slavery and by the later virulent measures used to maintain white supremacy created a segregative penal solution consistent with the dominant public image of criminals as members of a vile racial underclass. This racial history and the resulting cultural premises helped to produce a criminal justice system that primarily uses incapacitation to control street crime. The most reliable way to incapacitate incorrigible offenders is to kill them. This incapacitative solution fits with the prevailing public view-often forcefully expressed politically in this most direct of all large democracies - that the primary goal of the U.S. criminal justice system should be vengeance.

Executions therefore should be most likely in jurisdictions in which covertly racist law and order political appeals have been most successful and where the presence of a large African American population - that has not become quite large enough to enforce its political values - threatens dominant whites. Prior research supports such political and racial results. Findings show that the same aggregate political and racial factors account for the likelihood that a state will legalize the death penalty (Jacobs and Carmichael 2002). In another study, Jacobs and colleagues (2005) report that similar political and racial factors explain the number of death sentences. But compared to these two studies and other aggregate-level research, this investigation is unique as it analyzes both state and individual characteristics. Probably the most important finding that emerges from this multilevel approach concerns victim race. African Americans who breach the racial caste system by killing whites can more often expect the harshest of all penalties, and this finding holds after many contextual level political and racial effects have been held constant. Such results do not contradict Wacquant's (2000, 2001 ) theoretical claims that a primary goal in the current U.S. criminal justice system is to sustain the prior racial caste system even though the current methods are less transparent than the lawless brutality used in the past. ${ }^{20}$

The most important legal implication concerns racial equity. Many claims have been made that the U.S. criminal justice system is not colorblind, yet after multiple studies, definitive evidence showing that the trial courts sentence African Americans less leniently than whites has remained elusive. This study instead analyzed racial effects on the post-sentencing execution process. The findings show that despite efforts

\footnotetext{
${ }^{20}$ For additional findings on how past racial, ethnic, or religiously based brutality continues to affect current practices, see Archer and Gartner (1984), Messner, Baller, and Zevenbergen (2005), Savelsberg and King (2005), and Jacobs and colleagues (2005).
} 
to transcend an unfortunate racial past, residues of this fierce discrimination evidently still linger, at least when the most morally critical decision about punishment is decided. Findings indicating that African Americans who kill nonwhites are less likely to be executed than their counterparts who kill whites show that the post-sentencing capital punishment process continues to place greater value on white lives. Evidently, inclinations to devalue African Americans in constitutional compromises in the distant past remain today, although they are expressed in less conspicuous ways. Associate Justice William Brennan helps us understand the importance of such discriminatory findings:

Those whom we would banish from society or from the human community itself often speak in too faint a voice to be heard above society's demand for punishment. It is the particular role of the courts to hear these voices, for the Constitution declares that the majoritarian chorus may not alone dictate the conditions of social life. (Brennan 1987)

This evidence shows that the state and federal appellate courts - who should pay special attention to those accused of the most horrific crimes - evidently continue to listen to some voices more than others.

David Jacobs is Professor of Sociology and (by courtesy) Political Science at The Ohio State University. He uses a political economy approach to study outcomes in the criminal justice system and other issues in political sociology. A study of racial politics recently appeared in the American Journal of Sociology while another publication on the determinants of yearly execution frequencies will soon appear in Social Problems. In addition to these interests, he continues to investigate the politics of labor relations.

Zhenchao Qian is Professor in the Department of Sociology and research associate in the Initiative in Population Research at The Ohio State University. His research focuses on family demography, race and ethnicity, and immigration. He studies changes in mate selection by taking into account marriage market conditions. His work with Daniel T. Lichter, recently published in American Sociological Review, centers on changes in racial/ethnic intermarriage. His other research examines changing racial identification among children born to interracial couples.

Jason T. Carmichael is an Assistant Professor in the Department of Sociology at McGill University. His interests include criminology, criminal justice, and, more broadly, political sociology. Current projects include, among other things: an analysis of the political and social determinants of the number of juve- nile delinquents who are adjudicated in the adult criminal justice system, and an examination of the ability of foundation funding to shape the size and/or success of social movement organizations.

Stephanie L. Kent is an Assistant Professor of Sociology at Cleveland State University. Her research focuses on the politics of crime control and uses macrosocial explanations to predict social control outcomes. Recent publications include a pooledtime-series analysis of police strength in U.S. cities published in Criminology. Additional work on capital punishment has or will be published in the American Sociological Review and Social Problems. She is currently exploring the social and political determinants of homicide and the use of lethal force by and against the police in U.S. cities.

\section{REFERENCES}

Aarons, Dwight. 1998. "Getting Out of this Mess: Steps Toward Addressing and Avoiding Inordinate Delay in Capital Cases." Journal of Criminal Law and Criminology 89:1-58.

Allen, Michael P. and John L. Campbell. 1994. "State Revenue Extraction from Different Income Groups." American Sociological Review 59:169-86.

Archer, Dane and Rosemary Gartner. 1984. Violence and Crime in Cross-National Perspective. New Haven, CT: Yale University Press.

Bailey, William C. and Ruth Peterson. 1999. "Capital Punishment, Homicide, and Deterrence.” Pp. 257-77 in Homicide: A Sourcebook, edited by M. D. Smith and M. A. Zahn. Thousand Oaks, CA: Sage.

Baldus, David C. and George Woodworth. 2003. "Race Discrimination in the Administration of the Death Penalty: An Overview of the Empirical Evidence with Special Emphasis on the Post-1990 Research." Criminal Law Bulletin 39:194-226.

Bandes, Susan. 2004. "Fear Factor: The Role of Media in Covering and Shaping the Death Penalty." Ohio State Journal of Criminal Law 1:585-97.

Beckett, Katherine. 1997. Making Crime Pay. New York: Oxford.

Berry, William D., Evan J. Ringquist, Richard C. Fording, and Russell L. Hanson. 1998. "Measuring Citizen and Government Ideology in the States." American Journal of Political Science 42:327-48.

Bickle, Gayle and Ruth Peterson. 1991. "The Impact of Gender Based Family Roles on Criminal Sentencing." Social Problems 38:372-94.

Blalock, Hubert M. 1967. Towards a Theory of Minority Group Relations. New York: Capricorn Books.

Blume, J. and Theodore Eisenberg. 1999. "Judicial Politics, Death Penalty Appeals, and Case 
Selection." Southern California Law Review 72:465-503.

Blumer, Herbert. 1958. "Race Prejudice as a Sense of Group Position." Pacific Sociological Review $1: 3-7$.

Bobo, Lawrence and Vincent Hutchings. 1996. "Perceptions of Racial Group Competition: Extending Blumer's Theory of Group Position in a Multiracial Social Context." American Sociological Review 61:951-72.

Brace, Paul and Melinda G. Hall. 1997. "The Interplay of Preferences, Case Facts, Context, and Rules in the Politics of Judicial Choice." Journal of Politics 59:1206-23.

Brennan, William J. 1987. Dissent in McClesky v. Kemp (481 U.S. 279, 343).

Bright, Stephen B. and Patrick J. Keenan. 1995. "Judges and the Politics of Death: Deciding Between the Bill of Rights and the Next Election in Capital Cases." Boston University Law Review 75:759-835.

Brown, Craig and Barbara Warner. 1992. "Immigrants, Urban Politics, and Policing in 1900." American Sociological Review 57:293-305.

Carter, Dan T. 1996. From George Wallace to Newt Gingrich: Race in the Conservative Counterrevolution, 1963-1994. Baton Rouge, LA: Louisiana State University Press.

Chambliss, William J. 1994. "Policing the Ghetto Underclass: The Politics of Law and Law Enforcement." Social Problems 41:177-94.

Chiricos, Theodore G. and Charles Crawford. 1995. "Race and Imprisonment." Pp. 281-309 in Ethnicity, Race, and Crime, edited by D. Hawkins. Albany, NY: SUNY Press.

Chiricos, Theodore G. and Miriam Delone. 1992. "Labor Surplus and Punishment: A Review and Assessment of Theory and Evidence." Social Problems 39:421-46.

Cohen, Jacob, Patricia Cohen, Stephen D. West, and Leona S. Aiken. 2003. Applied Multiple Regression/Correlation Analysis for the Behavioral Sciences. 3d ed. Hillsdale, NJ: Lawrence Erlbaum Associates.

Constanzo, Mark. 1997. Just Revenge: The Costs and Consequences of the Death Penalty. New York: St. Martins Press.

Dodge, Lowell, Laurie E. Eckland, Harriet C. Ganson, Lisa Cassady, James L. Flemming, and Douglas M. Sloan. 1990. "Death Penalty Sentencing." Pp. 268-74 in Death Penalty in America, edited by $\mathrm{H}$. A. Bedau. New York: Oxford.

Donohue, John J. and Justin Wolfers. 2005. "Uses and Abuses of Empirical Evidence in the Death Penalty Debate." Stanford Law Review 58:791-845.

Ehrlichman, John D. 1982. Witness to Power: The Nixon Years. New York: Simon \& Schuster.

Fosset, Mark A. and K. Jill Kiecolt. 1989. "The Relative Size of Minority Populations and White
Racial Attitudes." Social Science Quarterly 70:820-35.

Foucault, Michel. 1977. Discipline and Punish. London: Vintage.

Fowler, Linda L. 1982. "How Interest Groups Select Issues for Rating Voting Records of Members of the U.S. Congress." Legislative Studies Quarterly 7:401-13.

Furman v. Georgia. 1972. 408 U.S. 238.

Garland, David. 1990. Punishment and Modern Society. Chicago, IL: University of Chicago Press.

. 2001. The Culture of Control. Chicago, IL: University of Chicago Press.

Giles, Michael W. and Melanie A. Buckner. 1993. "David Duke and Black Threat." Journal of Politics 55:702-13.

Giles, Michael W. and Kaenan Hertz. 1994. "Racial Threat and Partisan Identification." American Political Science Review 88:317-26.

Goldfield, Michael. 1997. The Color of Politics. New York: New Press.

Gregg v. Georgia. 1976. 96 Sup. Ct. 2902.

Hale, Chris. 1996. "Fear of Crime: A Review of the Literature." International Review of Victimology 4:79-150.

Heer, David M. 1959. "The Sentiment of White Supremacy: An Ecological Study." American Journal of Sociology 64:592-98.

Helms, Ronald and David Jacobs. 2002. "The Political Context of Sentencing: An Analysis of Community and Individual Determinants." Social Forces 81:577-604.

Herrera, Richard, Thomas Epperlein, and Eric R. A. N. Smith. 1995. "The Stability of Congressional Roll-Call Indexes." Political Research Quarterly 48:403-16.

Hood, Roger. 1998. "Capital Punishment." Pp. 739-76 in The Handbook of Crime and Punishment, edited by M. Tonry. New York: Oxford University Press.

Hurwitz, Jon and Mark Peffley. 2005. "Playing the Race Card in the Post-Willie Horton Era." Public Opinion Quarterly 69:99-112.

Jacobs, David. 1979. "Inequality and Police Strength: Conflict Theory and Coercive Control in Metropolitan Areas." American Sociological Review 44:913-25.

Jacobs, David and Jason T. Carmichael. 2001. "The Politics of Punishment Across Time and Space." Social Forces 80:61-89.

- 2002. "The Political Sociology of the Death Penalty: A Pooled Time-Series Analysis." American Sociological Review 67:109-31.

Jacobs, David, Jason T. Carmichael, and Stephanie L. Kent. 2005. "Vigilantism, Current Racial Threat, and Death Sentences." American Sociological Review 70:656-77.

Jacobs, David and Ronald Helms. 1996. "Towards a Political Model of Incarceration: A Time-Series 
Examination of Multiple Explanations for Prison Admission Rates." American Journal of Sociology 102:323-57.

Jacobs, David and Robert M. O’Brien. 1998. “The Determinants of Deadly Force: A Structural Analysis of Police Violence." American Journal of Sociology 103:837-62.

Jacobs, David and Daniel B. Tope. 2007. "The Politics of Resentment in the Post Civil-Rights Era: Minority Threat, Homicide, and Ideological Voting in Congress." American Journal of Sociology 113:1458-94.

Johnston, Jack. 1984. Econometric Methods. New York: McGraw-Hill.

Kent, Stephanie L. and David Jacobs. 2005. "Minority Threat and Police Strength from 1980 to 2000: A Fixed-Effects Analysis of Nonlinear and Interactive Effects in Large U.S. Cities.' Criminology 43:731-60.

Key, V. O. 1949. Southern Politics. New York: Vintage Books.

Lacey, Nicola. 1988. State Punishment. London: Routledge.

Lakoff, George. 1996. Moral Politics. Chicago, IL: University of Chicago Press.

Langworthy, Robert H. and John T. Whitehead. 1986. "Liberalism and Fear as Explanations for Punitiveness." Criminology 24:575-91.

Levitt, Steven D. 2002. "Deterrence.” Pp. 435-50 in Crime: Public Policies for Crime Control, edited by J. Q. Wilson and J. Petersillia. Oakland, CA: ICS Press.

Liebman, James S., Jeffrey Fagan, and Valerie West. 2000. "A Broken System: Error Rates in Capital Cases, 1973-1995.” Report, Columbia University Law School.

2002. "A Broken System, Part II: Why

There is so Much Error in Capital Cases, and What Can be Done About It." Report, Columbia University Law School.

Lipschultz, Jeremy H. and Michael L. Hilt. 2002. Crime and Local Television News: Dramatic, Breaking, and Live from the Scene. Mahwah, NJ: Lawrence Erlbaum Associates.

Liska, Allen E., J. J. Lawrence, and A. Sanchirico. 1982. "Fear of Crime as a Social Fact." Social Forces 60:760-71.

Lofquist, William S. 2002. "Putting Them There, Keeping Them There, and Killing Them: An Analysis of State-Level Variations in Death Penalty Intensity." Iowa Law Review 87:1505-57.

Manski, Charles F. and Steven R. Lerman. 1977. "Estimation of Choice Probabilities from Choice Based Samples." Econometrica 45:1977-89.

Messner, Steven F., Robert D. Baller, and Matthew P. Zevenbergen. 2005. "The Legacy of Lynching and Southern Homicide." American Sociological Review 70:633-55.

Myers, Martha A. and Suzette M. Talarico. 1987.
The Social Contexts of Criminal Sentencing. New York: Springer-Verlag New York Inc.

Myrdal, Gunnar. 1944. An American Dilemma. New York: Harper and Brothers.

Paternoster, Raymond. 1991. Capital Punishment in America. New York: Lexington Books.

Perrow, Charles. 1986. Complex Organizations: A Critical Essay. New York: Random House.

Poole, Keith T. and Howard Rosenthal. 2000. Congress: A Political-Economic History of Roll Call Voting. New York: Oxford University Press.

Prentice, R. L. and R. Pyke. 1979. "Logistic Disease Incidence Models and Case-Control Studies." Biometrika 66:403-11.

Quillian, Lincoln. 1996. "Group Threat and Changes in Regional Change in Attitudes Toward AfricanAmericans." American Journal of Sociology 102:816-60.

Quillian, Lincoln and Devah Pager. 2001. "Black Neighbors, Higher Crime? The Role of Racial Stereotypes in Evaluations of Neighborhood Crime." American Journal of Sociology 107:717-67.

Rogers, William H. 1993. "Regression Standard Errors in Clustered Samples." Stata Technical Bulletin 13:1923-28.

Rusche, Georg and Otto Kirchheimer. 1939. Punishment and Social Structure. New York: Russell and Russell.

Savelsberg, Joachim J. 1994. "Knowledge, Domination, and Criminal Punishment." American Journal of Sociology 99:911-43.

Savelsberg, Joachim J. and Ryan D. King. 2005. "Institutionalizing Collective Memories of Hate: Law and Law Enforcement in Germany and the United States." American Journal of Sociology 111:579-616.

Scott, W. Richard. 1987. Organizations: Rational, Natural, and Open Systems. Englewood Cliffs, NJ: Prentice Hall.

Shaffer, William R. 1989. "Rating the Performance of the ADA in the U.S. Congress." Western Political Quarterly 42:33-51.

Spurr, Stephen J. 2002. "The Future of Capital Punishment: Determinants of the Time from Death Sentence to Execution." International Review of Law and Economics 22:1-23.

Stucky, Thomas D., Karen Heimer, and Joseph B. Lang. 2005. "Partisan Politics, Electoral Competition, and Imprisonment." Criminology 43:211-48.

Sutton, John. 2000. "Imprisonment and Social Classification in Five Common-Law Democracies, 1955-1985." American Journal of Sociology 106:350-86.

Taylor, Ian, P. Walton, and Jock Young. 1973. The New Criminology. London: Routledge and Kegan Paul.

Taylor, Marylee C. 1998. "How White Attitudes Vary 
with the Racial Composition of Local Populations." American Sociological Review 63:512-35.

Thorne, Melvin J. 1990. American Conservative Thought Since World War II. New York: Greenwood Press.

Tocqueville, Alexis de. 1948. Democracy in America. New York: Knopf.

Turk, Austen. 1969. Criminality and the Legal Order. Chicago, IL: Rand McNally.

Uniform Crime Reports [United States]. "Supplementary Homicide Reports, Various Years." Ann Arbor, MI: Inter-University Consortium for Political and Social Research.

United States Department of Justice, Bureau of Justice Statistics. 2003. "Capital Punishment in the United States, 1973-2002.” Ann Arbor, MI: InterUniversity Consortium for Political and Social Research.

Wacquant, Loic. 2000. "The New Particular Institution: On the Prison as Surrogate Ghetto." Theoretical Criminology 4:377-89.

. 2001. "Deadly Symbiosis: When Ghetto and Prison Meet and Mesh.” Punishment \& Society 3:95-134.

Walker, Samuel, Cassia Spohn, and Miriam DeLone. 1996. The Color of Justice: Race, Ethnicity, and Crime in America. Belmont, CA: Wadsworth.

Weidner, Robert R. and Richard S. Frase. 2003. "Legal and Extralegal Determinants of Intercounty Differences in Prison Use." Criminal Justice Policy Review 14:377-400.

Western, Bruce. 2006. Punishment and Inequality in America. New York: Russell Sage Foundation.

Whitman, James Q. 2003. Harsh Justice: Criminal Punishment and the Widening Divide Between America and Europe. New York: Oxford.

Xie, Yu and Charles P. Manski. 1989. "The Logit Model and Response-Based Samples." Sociological Methods and Research 17:283-302.

Zatz, Marjorie S. 1987. "The Changing Forms of Racial/Ethnic Biases in Sentencing." Journal of Research in Crime and Delinquency 24:69-92.

Zimring, Franklin E. and Gordon Hawkins. 1986. Capital Punishment and the American Agenda. New York: Cambridge. 